\title{
THE BIRDS OF
}

\section{DINOSAUR PROVINCIAL PARK, ALBERTA}

NORBERT G. KONDLA, Parks Planning \& Design Branch, Alberta Recreation, arks \& Wildlife, 9912 - 106 Street, Edmonton

Dinosaur Provincial Park contains some of the finest badlands terrain in Canada and is internationally known for its numerous dinosaurian fossils. However, relatively little is known of the natural history of this fascinating area. Other than reports in 1919 and 1946, little information is available concerning the avifauna of the area. ${ }^{17} 14$ This paper deals with the irds of the park based on obervations made in 1971 for the Alberta Department of Lands and orests.?

METHODS. From May 17 to August 7. 1971, the winter and Hugh rawford conducted general natural istory surveys in the park. Major hysiographic subdivisions of the park vere investigated by 15 prairie visits, 0 terrace investigations and 27 adlands excursions. Two boat trips vere made along the Red Deer River.

During the field trips, notes were rade on birds and other animals seen r heard. Observations were made on eneral vegetation distribution and omposition. Vascular plant voucher pecimens were collected and idenfied with the assistance of Dr. J. Kuijt. pecimens are deposited with the Iniversity of Calgary and University of ethbridge herbaria.

\section{PARK ENVIRONMENT. Dinosaur} ark is in the prairie region of Alberta, pproximately $48 \mathrm{~km}$ northeast of rooks. The surface area is about 8800 a. Altitude varies from $610 \mathrm{~m}$ to 747 and the Red Deer River flows from est to east through the park.

The park lies in one of the hottest nd driest regions of the prairie provinces. Situated on the boundary between moist and dry steppe, the mean annual precipitation is only 330 $\mathrm{mm}$, of which $203 \mathrm{~mm}$ falls from May to September. ${ }^{12}$ Summer temperatures in the region are high; an average of 55 days per year have a maximum temperature above $26^{\circ} \mathrm{C}$. Local temperatures in the park are substantially higher due to microclimatic effects.

The park divides naturally into three physiographic regions: prairie, badlands, and river terrace (Fig. 1). Each region is characterized by distinct landform, vegetation and bird life.

About 15 percent of the park area is prairie. Surficial material is largely glacial till, with lesser areas of weathered bedrock, lacustrine material, and inactive sand dunes. Soils are predominantly solonetzic. ${ }^{4}$

Badlands occupy about 75 percent of the park. They consist of eroding claystones and sandstones of the Bearpaw formation. All the characteristic badlands features can be seen here: miniature pediments and fans, hoodoos, buttes and mesas, knife edge divides, a complex pattern of fluvial channels, and piping. 'Soil horizon development is negligible.

The remaining $10 \%$ of the park consists of terraces formed by the confined meanders of the river. ${ }^{13}$ These unique landforms are not purely terraces nor purely river floodplain. Deposition of sandy levees creates low lying areas qualifying as floodplain. Subsequent deposition of eroded 


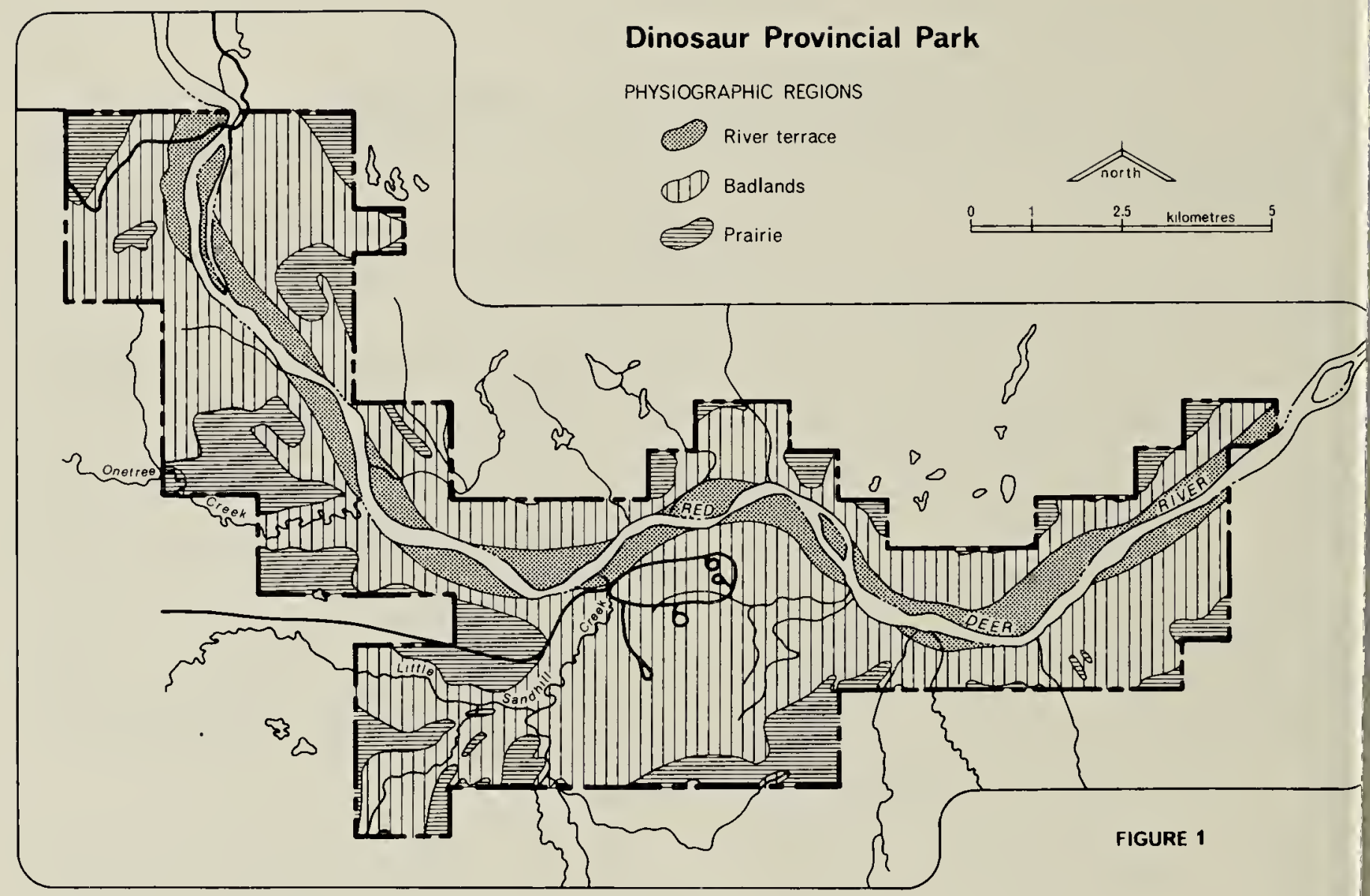

materials from the badlands and downcutting by the river has raised the older portions of the terraces sufficiently to place them beyond the reach of floodwater and therefore qualify them as terraces. Between the recently deposited levees and bona fide terrace is an area where old levees are still visible as ridges. This area is indeterminate in terms of matching the classical concept of terrace or floodplain.

Prairie vegetation is of the mixed grass type and is dominated by blue grama grass (Bouteloua gracilis), June grass (Koeleria cristata), and spear grass (Stipa comata). Common forbs are wild onion (Allium textile), pasture sage (Artemisia frigida), cushion cactus (Mamillaria vivipara) and scarlet mallow (Sphaeralcea coccinea). Prickly pear cactus (Opuntia polyacantha) is common in blow-outs. Little club moss (Selaginella densa) and broomweed (Gutierrezia sarothrae) are abundant in heavily grazed areas but, in general, the range has been well treated.

Badlands offer an intricate variety of vegetation types that appear to be strongly controlled by slope aspect, physical- chemical characteristics of the substrat and fluvial process.

Characteristic plants of the barre eroding slopes and pediments are: sever species of saltbrush (Atriplex spp greasewood (Sarcobatus vermiculatus rubberweed (Hymenoxys richardsonii), b sagebrush (Artemisia cana), and narrov leaved sage (Artemisia longifolia). Individu plants are invariably widely spaced, wit expanses of bare ground separating then (Fig. 2)

Major northerly facing slopes and a jacent valley bottoms frequently suppo thickets of Prunus spp., saskatoc (Amelanchier alnifolia), and roses (Rosa spr with a luxuriant growth of mid-grasses ar forbs. Gentle southerly facing slop support forb-rich grassland with varyir amounts of sage (Artemisia spp.).

Larger pediments in the badlands zor frequently show a sandy veneer and suppo closed grassland vegetation with sandgra (Calamovilfa longifolia) and ricegra (Oryzopsis hymenoides). Characterist forbs of these grassy areas are breadro (Psoralea esculenta), Nuttall's ironpla (Haplopappus nuttallii), small blue lupiı (Lupinus pusillus), and sunflowe (Helianthus spp.). Very old pediments ha 
vegetation similar to the nearby prairie grassland with blue grama grass (Bouteloua gracilis) being the dominant species.

Wide badlands drainage channels with a natural hydrologic regime have an intermittent moisture supply and extensive sand deposits. Typical plants are big sagebrush, sandgrass, yellow sweet clover (Melilotus officinale), cocklebur (Xanthium strumarium) and alkali cordgrass (Spartina gracilis). Scattered individuals of plains cottonwood (Populus sargentii) and thorny buffaloberry (Shepherdia argentea) are present.

Onetree Creek, Little Sandhill Creek and two smaller drainage channels are fed by irrigation runoff. These have virtually continual flowing water during most of the growing season. Vegetation reflects this improved moisture regime. (Fig. 3) Present are stands dominated by three-angled rush (Scirpus americanus), cattail (Typha latifolia) and horsetails (Equisetum spp.). Tree and shrub cover is locally increased to the point that one can see small stands of plains cottonwood and a variety of shrubdominated vegetation types. Monocultures of thorny buffaloberry (Shepherdia argentea) and of sandbar willow (Salix interior) are present, as are mixed stands of silverberry (Elaeagnus commutata), rose (Rosa spp.), saskatoon (Amelanchier alnifolia) and chokecherry (Prunus pennsy/vanica).

The river terraces and point bar complexes support very distinct plant communities in accordance with the age of the deposits and the amount and type of sediments transported from the adjacent badlands. (Fig. 4). Recent sand deposits are colonized by species such as red goosefoot (Chenopodium rubrum), sneezeweed (Helenium autumnale), common plantain (Plantago major), sandbar willow, and plains cottonwood (Populus sargentii). With in creasing age and height, tall, dense thickets of sandbar willow with a rapidly developing plains cottonwood understory appear. Successively older stands of plains cottonwood are present above the usual flood level. (Fig. 5). Shub cover is usually well developed and includes water birch (Betula occidentalis), buckbrush (Symphoricarpos occidentalis), dogwood (Cornus stolonifera), thorny buffaloberry (Shepherdia argentea) and the vine, western clematis (Clematis ligusticifolia)

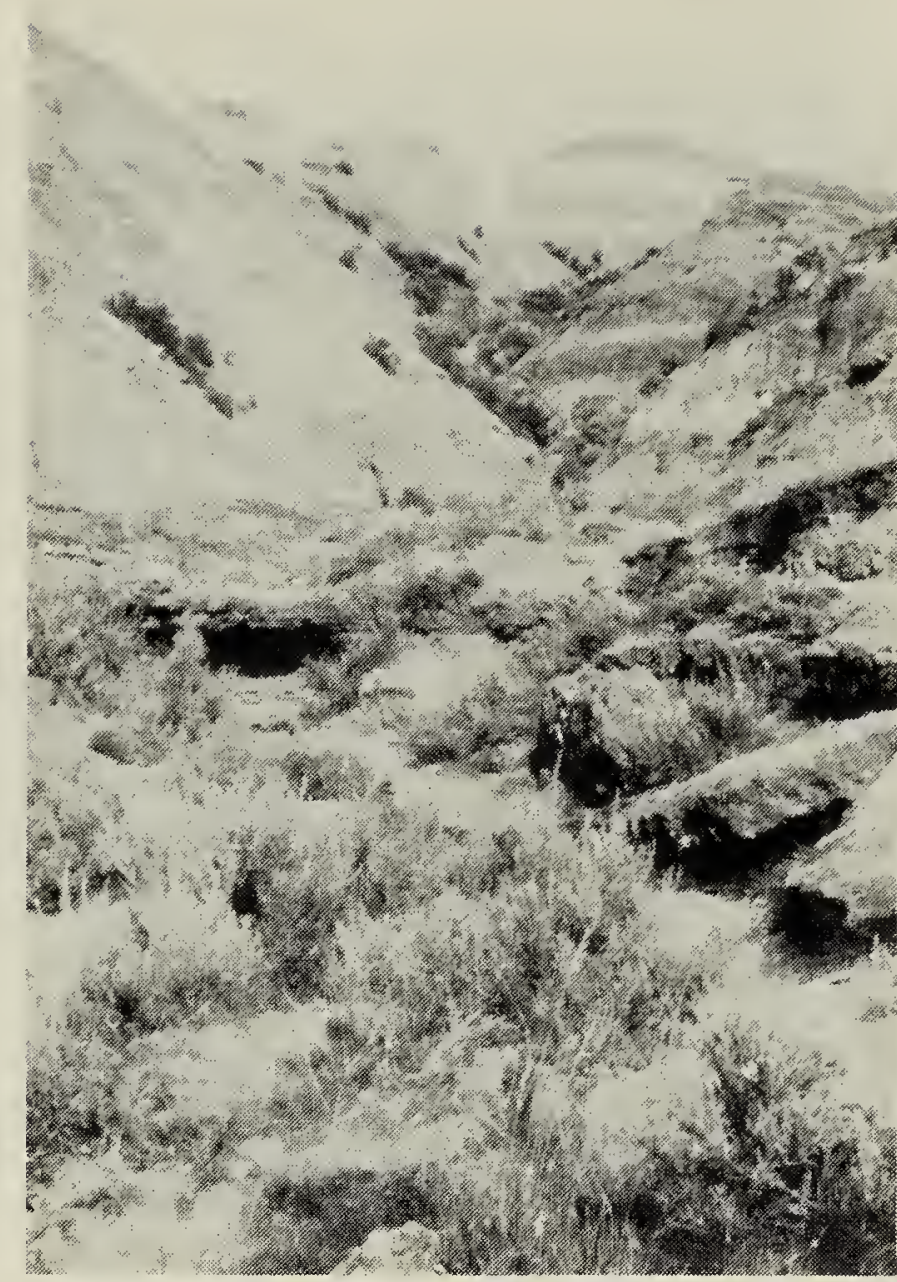

Fig. 2: Typical badlands vegetation dominated by open plant communities.

Above these treed areas and subject to deposition by sediment eroded from the badlands occur the sagebrush flats dominated by big sagebrush. Also present here are greasewood, western wheat grass (Agropyron smithii), sand grass, giant wild rye (Elymus cinereus), and poverty weed (Iva axillaris).

ANNOTATED LIST OF BIRDS. This list is based on observations by $N$. Kondla in 1971, sporadic observations by N. Kondla and H. Pinel from 1966 to 1970, Randall from 1943 through 1945, observations by C. Wallis in 1975 and 1977, observations by C. Wershler in 1977, and Taverner at his camp, July 19 - September 26, 1917.1417 Species of which nests or young birds were seen are indicated by **. Species suspected of breeding in the park by virtue of birds being present in suitable habitat during the usual breeding season are indicated by * 


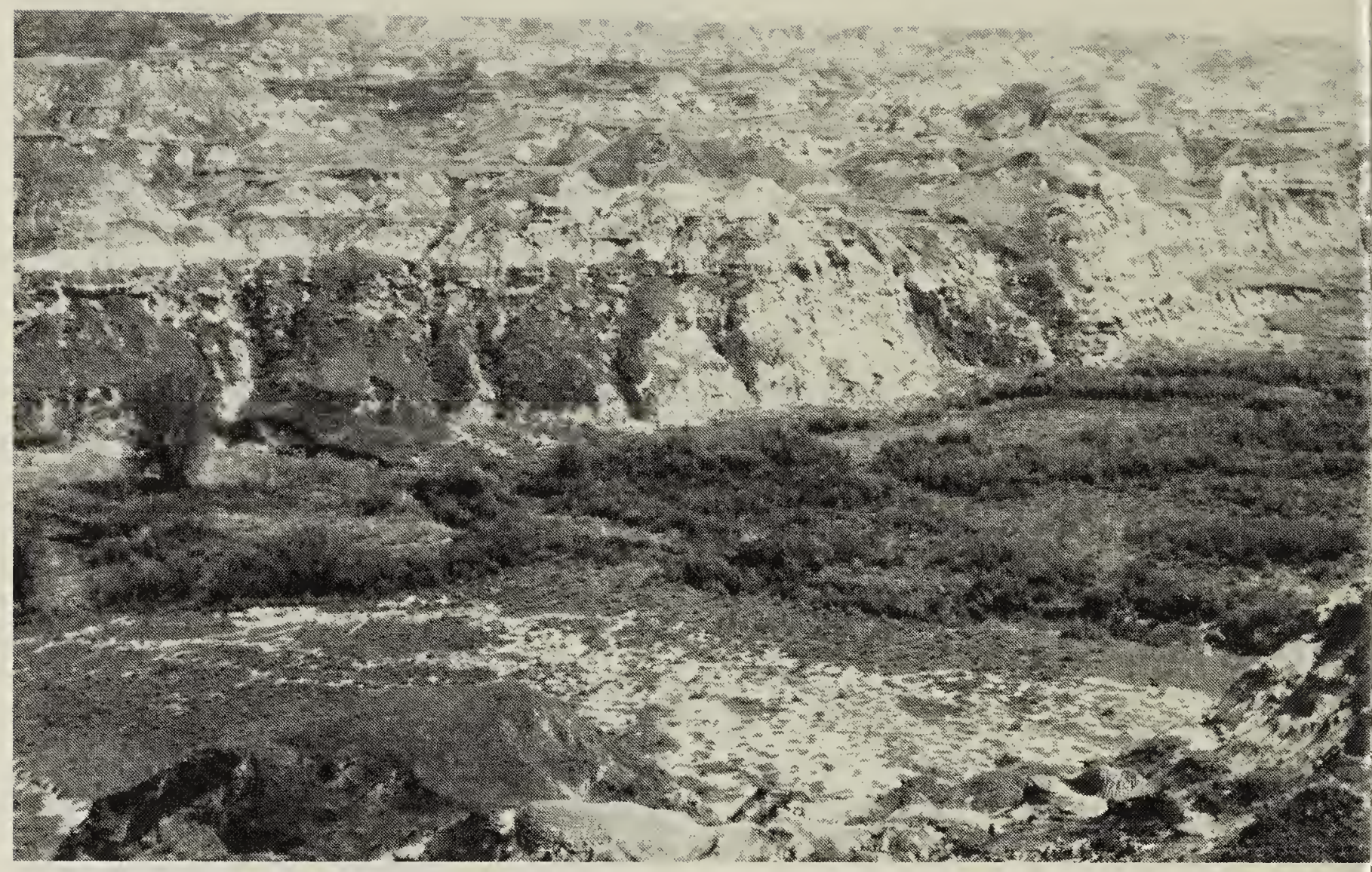

Fig. 3: Valley of Little Sandhill Creek showing the enriched shrub growth due to irrigatic activity in the region.

Horned Grebe - Visitor during summer and migrations; no suitable nesting habitat; two birds reported during late summer, 1917, by Taverner.

Western Grebe - One bird was seen on the river at the administration site on July 15 , 1971

White Pelican - Taverner reported one bird June 24

** Great Blue Heron - Recorded by Taverner and also by Randall who stated that they may nest along the Red Deer or Bow Rivers. ${ }^{17}{ }^{14}$ On June 24, 1971, a colony on an island in the Red Deer River near the western edge of the park was examined. It contained 41 nests, most with young almost ready to $\mathrm{fly}$, in 9 large old cottonwoods. Vermeer reported 32 nests in this colony in 1967. ${ }^{19}$ Adults were often seen in small groups along the river in 1971. Colony still active in 1975

American Bittern - Taverner reported one bird on August 22, 1917.

**Canada Goose - Adults were occasionally seen flying along the river and over the badlands. On June 7, 1971, goslings were seen leaving an old Ferruginous Hawk nest on a cliff. ${ }^{6}$ On July 22, 1971, 34 flightless birds were seen in a group on the river. Some birds dove as our boat ap- proached while others ran into the willov on shore. Dzubin indicates that this specis is widespread as a breeding bird along th lower Red Deer River. ${ }^{2}$ Adults with your were seen on quiet river channels May 27 28, 1975.

Snow Goose - One bird in 1917.

*Mallard - Seen occasionally along th river and Little Sandhill Creek.

**Pintail - Seen a few times on the riv and the upper reaches of Little Sandh Creek. Also reported in 1917.

American Green-winged Teal - Flyir young seen on August 15 and 23, 1917

Blue-winged Teal - Seen June 18, 1971, c Little Sandhill Creek. Also reported August 24, 1917

American Wigeon - Seen June 18, 1971, c Little Sandhill Creek.

Northern Shoveler - Reported on Augu 17 and $18,1917$.

**Common Goldeneye - A moultin flightless bird was seen on the river on Ju 22, 1971. Kondla and Pinel report a fema with downy young just outside the par indgrating the possibility of nesting with the park. ${ }^{8}$ At least four pairs seen May 27 28,1975 , on the Red Deer River.

Bufflehead - Two birds reported Se tember 14, 1917. 
Turkey Vulture - Taverner "saw aggregations of a dozen to twenty a number of times" in 1917. H. Sandgathe (pers. comm.) told of having seen a few birds every year until about 1968.

Gowhawk - One bird July 30, 1917.

Sharp-shinned Hawk - Several specimens were collected between August 27 and September 7, 1917, and they were "numerous" after mid-September of that year. ${ }^{17}$

Red-tailed Hawk - One bird was seen on June 23, 1971 just inside the southeastern park boundary. From 1943-45 a few pairs nested along this part of the Red Deer River. ${ }^{14}$

**Ferruginous Hawk - Taverner referred to this species as being very common. Randall also considered it to be a common nesting species in these badlands, $1943-45 .^{14}$ More than 119 nests were found throughout the badlands in 1971, indicating a long history of presence in the area. In spite of this, the breeding population appeared to be quite low and only two breeding pairs were confirmed by finding occupied nests in 1971. Two additional localities with hawks present indicated probable nesting sites. One of the occupied nests contained four eggs on May 20, four downy young on June 8 and was empty on July 1 . The other occupied nest contained three downy young. Although it is difficult to say exactly why this species is presently so uncommon, it is perhaps significant that only one Richardson's Ground Squirrel was seen in the park in 1971.

${ }^{*}$ * Golden Eagle - Only two birds were seen in the park in 1971 but the author and $\mathrm{H}$. Pinel have observed a pair nesting here from 1966-1970. Randall also reported a nesting pair. ${ }^{14}$ Another nest site was located in 1971 and J. Fryberger showed the author a nest near his home that has been used annually for the past 20 years. One adult was seen May 27, 1975, near Fryberger's and 1 on May 28 at east boundary hunting along the south slopes of valley.

Marsh Hawk - Taverner reported that the species became common in late summer, probably on migration. There is very little suitable habitat for the species in the park. Only three birds were seen in 1971

**Prairie Falcon - Taverner secured eight specimens along Little Sandhill Creek in 1917 and Randall considered this species to be common, from 1943 through $1945 .{ }^{17}{ }^{14}$
Their status has apparently not changed. In 1971, four breeding pairs were confirmed by observing the young in the eyrie. An additional six localities were noted with suitable nesting sites and adult falcons present. Tavener reported young had left two nests by July 19, 1917.

Peregrine Falcon - Randall referred to it as a common summer resident, nesting along the Red Deer River. ${ }^{14}$ The fifth A.O.U. Checklist of North American Birds listed Deadlodge Canyon as a breeding site. As no birds were seen in 1971 despite intensive searching, it is likely that this species no longer nests in the park. It is not clear whether or not the species was present in 1917.

** Merlin - Thirteen birds were collected in late summer and early fall, 1917. H. Pinel (pers. comm.) found a nest with six eggs on May 19, 1969. At least three pair nested in the park in 1971. With one exception birds were never seen far from the cottonwood stands along the river. Approximately one bird was seen per mile of river from Steveville to Jenner in 1975. Also common further downstream.

**Kestrel - Taverner found the species to be common in 1917 but made no specific references to birds in the park area. Birds were seen on six occasions in 1971 including a pair with two young on the wing on July 22.

* Sharp-tailed Grouse - Four birds were collected between July 27 and September 13,1917 . Four birds were seen in a sagebrush a rea on June 3, 1971

${ }^{*}$ Ring-necked Pheasant - A few males were seen in May and birds heard occasionally thereafter. The species was not as abundant as one would expect, considering the proximity to a pheasant hatchery and an area noted for its fine pheasant hunting.

Sora - Reported by Taverner from an area that may well have been outside the present park boundary since only intermittent sloughs occur within the park.

* Killdeer - Taverner recorded five birds on August 23, 1917. Birds were fairly common on the prairie but were never seen along the river or even the most extensive level areas in the badlands.

Common Snipe - Several specimens were collected on August 16, 1917

* Long-billed Curlew - Birds were seen occasionally on the prairie in 1971. Nested along western boundary in 1977 (Wershler). 


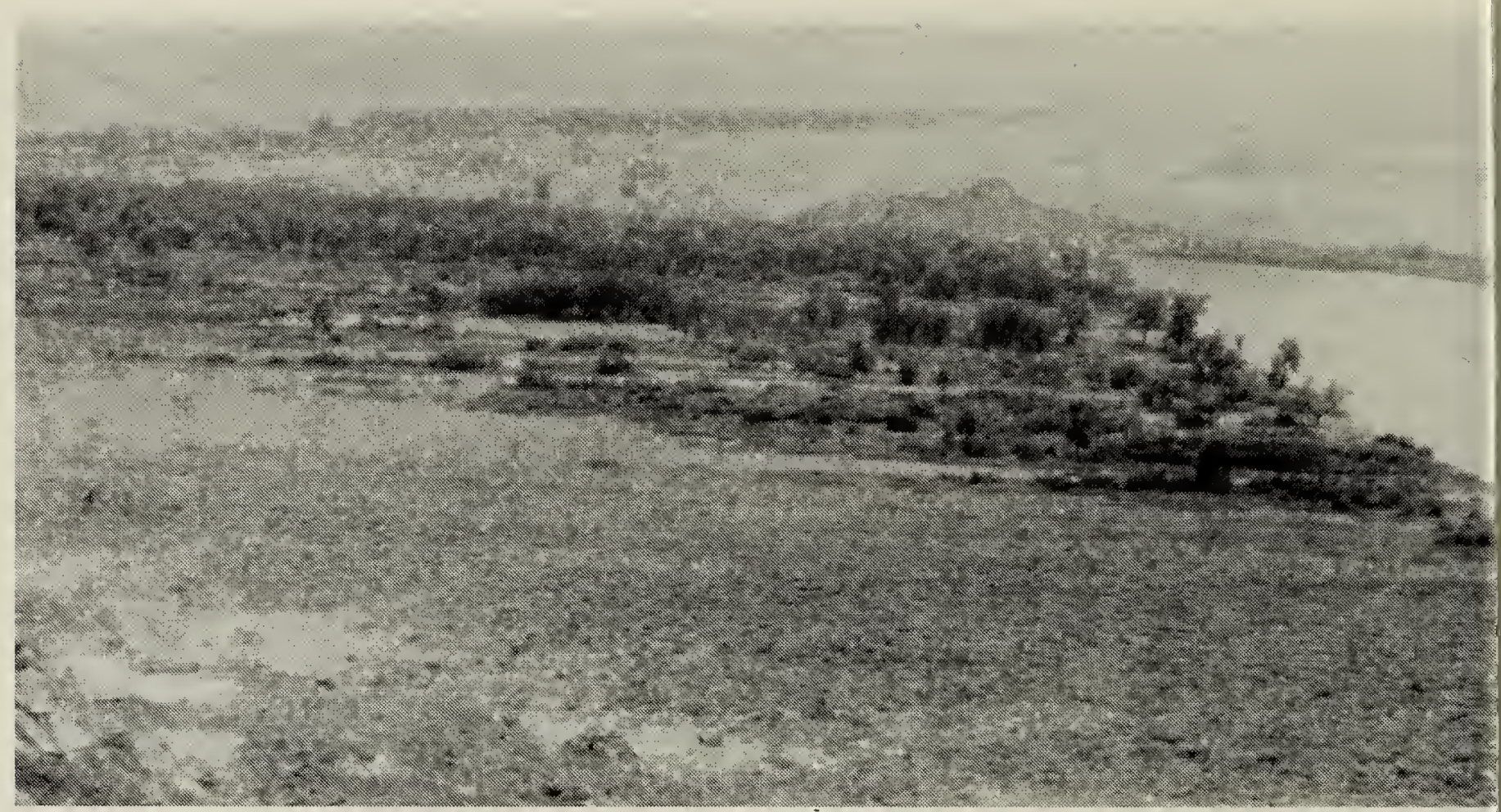

Fig. 4: Well developed vegetation zonation on river terrace and point bar complex. Not sharp habitat boundaries.

Upland Sandpiper - One was seen in rich Stipa-Koeleria grassland on July 28, 1971.

${ }^{*}$ Spotted Sandpiper - Birds were regularly seen along the river. Also reported nesting there by Taverner and by Randall. ${ }^{17} 14$

Willet - Seen only twice in the park but frequently on the prairie outside the park.

Taverner reported three birds on the river in 1917.

Greater Yellowlegs - Three birds were seen along the river on August 11, 1971.

American Avocet - One bird was observed along the river on July 13, 1971.

Marbled Godwit - Infrequently seen on the prairie in the park.

California Gull - Regularly seen in small numbers along the river and flying over the prairie

Wing-billed Gull - Status similar to California Gull. On June 7, 1971, one bird was feeding at the small dump near park headquarters.

Franklin's Gull - One bird was collected on July 27, 1917. In 1971, birds were seen circling over the badlands on June 29.

Common Tern - Two were seen along the river downstream from the Steveville Bridge in 1971

${ }^{*}$ Rock Dove - Seen frequently in the badlands where nesting was confirmed. It is noteworthy that Taverner did not record this species in 1917.

${ }^{*}$ Mourning Dove - A common species in all habitats. Two nests were found in the badlands; one on a small ledge of a low clif and the other on a small hoodoo. Taverne saw only one bird and considered th species "not very common" in 1917.

${ }^{*}$ Great Horned Owl - Taverner collecte one bird. Birds were seen in the badlands o two occasions in 1971 and one bird was see by the author along Little Sandhill Creek i April 1966. Present in cottonwoods in 197 and 1977.

Short-eared Owl - Seen occasionally o the prairie and also reported for 1917.

*Saw-whet Owl - Wallis and Wershle discovered one bird calling on territory $\mathrm{Ma}$ 12, 1977. Photographed by Wershler.

${ }^{*}$ Common Nighthawk - Seen frequentl over the river terraces and badlands. O July 4, 1971, 15 to 20 birds were observer circling over the park headquarters shortl before a rainstorm. An aggregation of 25-3i birds was observed by Wershler on Augus 12, 1977.

Belted Kingfisher - One bird was seen Jun 8, 1971, at Berry Creek. Taverner remarker on the scarcity of the species along the Re Deer River and attributed it to th murkiness of the water.

*Common Flicker - A common inhabitan of the cottonwood stands along the river. I was frequently seen feeding on the grounc in badlands.

**Downy Woodpecker - First reports b) Wallis and Wershler in 1977. Cottonwoor 
tands.

Castern Kingbird - A fairly common nhabitant of cottonwood stands and areas of taller shrubs along drainage channels. averner's latest date was September 7 , 917.

Nestern Kingbird - Reported by Taverner hut, surprisingly, no birds were seen in 1971 ind none have been reported subsequently.

"Say's Phoebe - A very common nhabitant of the badlands. One occupied hest was discovered. ${ }^{5}$ Also reported as "quite common" in 1917 and as nesting in he 1943-45 period. ${ }^{17} 14$

raill's Flycatcher - Taverner considered he specimens collected on August 9 and 11, 917, as early migrants. I do not know if hese specimens are Willow or Alder lycatcher although the latter is more likely.

Least Flycatcher - A common nesting pecies in the cottonwood stands along the Ped Deer River, Little Sandhill Creek and Dnetree Creek. "Common" in 1917.

Western Wood Pewee - Specimens ollected from August 6 to 25, 1917. None lere recorded in 1971 although this was kely due to observer oversight. This species ccurs regularly in the extensive cotonwood stands downstream from the park Wallis). Reported in riverine woods by allis and Wershler in 1977.

*Horned Lark - Fairly common on the rairie but rarely seen in the badlands. One est with three eggs was found May 27, 971. Young found them "common" and ollected them until September 20, [1917]. ${ }^{17}$

*Bank Swallow - A common species seen lost often along the river. Apparently ommon until the end of July, 1917. The umerous sandy cutbanks along the river rovide suitable nesting sites and several olonies were found.

Rough-winged Swallow - Very noticeable ong the small streams in the badlands. robably also present along the river but no fort was made to identify this species mong the numerous Bank Swallows fually present. Not reported for 1917.

Barn Swallow - A scarce species seen Hy at park headquarters where it nested buildings. Although several old nests ere found in the badlands it appears that e species no longer nests in that habitat. A few each day until September 25 (1917)."

Cliff Swallow - An abundant but obtrusive species nesting in the badlands d on cliffs along the river. Twelve active conlonies were found and numerous old nests were observed. Old nests were seen to provide nesting sites for Mountain Bluebirds and House Wrens. Last date in 1917 was August 11.

${ }^{*}$ Black-billed Magpie - A common species. Most nests were seen in the thorny buffaloberry, this shrub offering excellent protection for the nests. Taverner reported that they invariably nested within 100 yards of a Red-tailed or Swainson's Hawk nest.

* Common Crow - Not as abundant as the magpie but regularly seen. Large flocks were reported in 1917 after mid-September

* Black-capped Chickadee - Occasionally seen in the cottonwood stands and also reported in 1917

Red-breasted Nuthatch - Young collected one on August 21, 1917. Several birds on August 18, 1977 (Wallis).

** House Wren - A common species found in a variety of habitats. Nests were found in a stump, deserted building, natural cavity in sandstone and an old Cliff Swallow nest. Also reported in 1917.

* Rock Wren - A very common and characteristic nesting species of the badlands. Both Randall and Taverner also reported it as such. The latest date was September 15, 1917

*Catbird - An uncommon nesting species in areas of tall shrubs. Reported by Taverner as "fairly common."

** Brown Thrasher - An occasional species of tall shrub areas. A nest with four eggs was found on May 31, 1971. Last date in 1917 was September 1

${ }^{*}$ Robin - A rather uncommon species restricted to the wooded areas during the breeding season. A nest with three eggs was found on May 31, 1971. Reported by Taverner as "common."

Hermit Thrush - Taverner reported one bird collected on September 22, 1917.

Swainson's Thrush - Taverner collected one bird collected on September 17, 1917

*Veery - A singing bird on July 15, 1971 indicates the possibility of resting in cottonwood stands. Not uncommon downstream to the Saskatchewan border (Wallis).

* Mountain Bluebird - One of the most common birds of the badlands. Randall and Taverner also reported this species. ${ }^{14} 17$

Ruby-crowned Kinglet - Taverner reported a specimen on August 29 and occasional birds seen from the end of August until September 26, 1917 when the expedition 


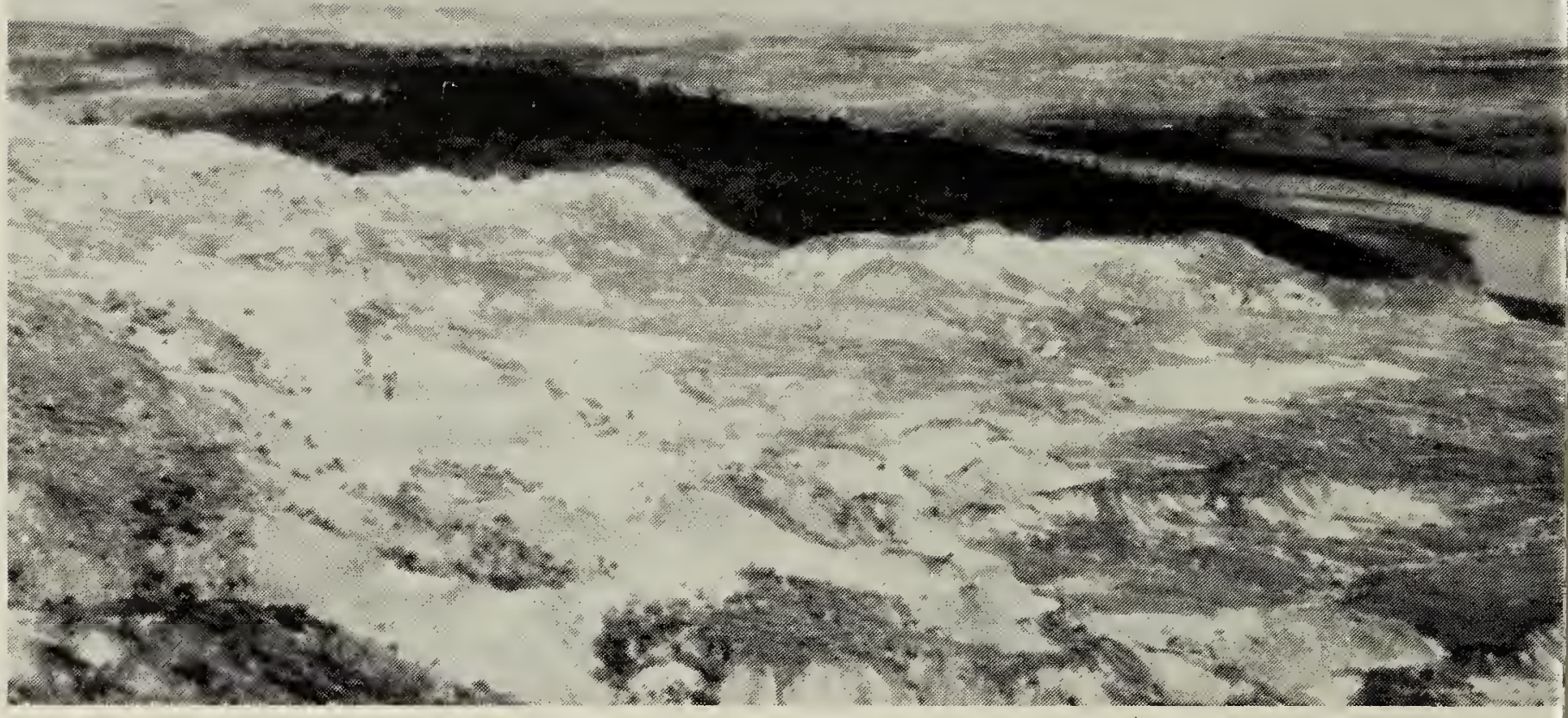

Fig. 5: Large stand of cottonwood and less rugged badlands.

ended

Water Pipit - Taverner reported large flocks from September 12 to 17, 1917

${ }^{*}$ Sprague's Pipit - A common species on the prairie. Seldom seen but regularly heard. Taverner reported a single specimen on September 13, 1917.

${ }^{*}$ Cedar Waxwing - An uncommon species of the cottonwood stands. Specimens were collected on July 20 and August 14, 1917.

Loggerhead Shrike - Taverner reported one or two families reared and two specimens July 21 and 28, 1917. In 1971 birds were seen near the park but not in the park.

${ }^{*}$ Starling - A rare species in the park. Only a few birds were seen at a recently abandoned farmhouse.

Solitary Vireo - Six birds were seen on September 1, 1917; one was collected.

${ }^{*}$ Red-eyed Vireo - Reported by Taverner from August 20 to September 1, 1917. Present in cottonwoods in 1977 (Wallis). Apparently overlooked in 1971.

*Warbling Vireo - Taverner reported a specimen on August 16, 1917. Present in cottonwood stands in 1977. (Wallis). Apparently overlooked in 1971.

Black and White Warbler - Taverner reported sight records and the collection of two specimens between August 13 and September 1, 1917.

Tennessee Warbler - Specimens collected on August 13,15, and 21, 1917. Also seen by Wallis on August 18, 1977.

Orange-crowned Warbler - Occasional birds seen and taken between August 25 ar September 17, 1917.

*Yellow Warbler - Farily common in lo and tall shrub habitats. Taverner reporte birds to be most common from August 9 September 8, 1917, with September 17 as $t$. last date.

Magnolia Warbler - Taverner reporte only two birds, both collected on Septemb $1,1917$.

Yellow-rumped Warbler - Tavern reported several collections and numero sightings from August 23 until at lea September 18, 1917. In 1971, one bird w seen May 10. All reports refer to the easi recognizable subspecies Dendroi coronata coronata (Myrtle Warbler).

Black-throated Green Warbler - Tavern recorded a single bird collected on Augc 17, 1917.

Blackpoll Warbler - Taverner reported t collection of two specimens on Septembe and a sight record August 28, 1917.

Palm Warbler - Young saw two birds September 1, 1917. ${ }^{17}$

Ovenbird - Taverner recorded $t$ collection of two birds, on August 27 al September 1, 1917.

Northern Waterthrush - Taverner report sight records and specimens during the $I_{c}$ week of August, 1917. Also seen August 1 1977 by C. Wershler.

Mourning Warbler - Young took o specimen August 17, 1917.

*Northern Yellowthroat - Tavern 
eported this species to be fairly common he last week in August, 1917. Frequently en in 1971 in low shrub vegetation and verine shrubs.

ellow-breasted Chat - Salt reports its resence in the extreme western portion of he park in the vicinity of the now nonxistent town of Steveville. ${ }^{16}$ In 1971 a bird as seen only on July 8 . The species seems be present in small numbers, although his may only be a manifestation of its ffinity for thickets of thorny buffaloberry here it has subsequently been reported ith regularity by others.

Vilson's Warbler - Taverner reported flections and numerous sightings from ugust 21 to September 18, 1917.

merican Redstart - Taverner reported a pecimen August 17 and sightings between ugust 26 and September 6, 1917. Also ported by Wallis and Wershler in August, 377.

House Sparrow - Only a few birds were en around park headquarters.

Western Meadowlark - Common on the airie in 1917, but only in late summer. In 971 , this was one of the most abundant and iquitous species in the park.

\section{ellow-headed Blackbird - Taverner} corded one bird.

Red-winged Blackbird - On July 6, sting birds were observed in an irrigation d drainage channel.

Northern Oriole - In 1971, the Baltimore riole (Icterus galbula galbula) was fairly mmon in the cottonwood stands. verner saw only two orioles and both cre Bullock's Oriole (Icterus galbula lllocki) collected August 29, 1917.

Brewer's Blackbird - A large migrant pck appeared in mid-September, 1917. irly common in 1971. Nine nests were und in 2 acres of Shepherdia and Armesia. ${ }^{8}$

Brown-headed Cowbird - Taverner ported one specimen August 2, 1917, and nsidered it to be generally "rather arce." Fairly common in 1971. Eggs were und in 4 of 9 Brewer's Blackbird nests. ${ }^{8}$ Ifous-sided Towhee was also parisitized.

estern Tanager - Young saw a few ound the last of August and first of ptember, $1917 .{ }^{17}$

pse-breasted Grosbeak - Taverner orted single birds August 19 and 20, 1917. ack-headed Grosbeak - Young felt that it s "not uncommon" during August, 1917; one collected on August 11. ${ }^{17}$ This species is not known to breed along the Red Deer River.

Purple Finch - Taverner reported one to five birds daily between August 18 and September 7, 1917. Also reported by Wallis and Wershler in August, 1977.

Pine Siskin - Single birds were seen August 15 and 22, 1917. Also reported by Wallis in August 1977.

*American Goldfinch - Young reported large flocks in early September, 1917. ${ }^{17}$ Fairly common in 1971

Red Crossbill - Taverner took a specimen July 21, 1917. It is interesting to note that Red Crossbills are quite regular in cottonwood stands of southern river valleys during summer (Wallis). Reported in park by Wershler August 12, 1977

** Rufous-sided Towhee - This species was common in 1917 and so it was in 1971 in treed and shrub areas. Two nests were found

Savannah Sparrow - Reported by Taverner to be scarce in August but numerous late in September. Not seen or heard in 1971 although I had expected to encounter it.

${ }^{*}$ Grasshopper Sparrow - One singing male in a sagebrush flat June 18, 1977 (Wallis).

LeConte's Sparrow - Occasional sight records and specimens reported by Taverner.

**Vesper Sparrow - Common in 1917 Fairly common in 1971 with apparent preference for escarpment preference for escarpment edges.

** Lark Sparrow - Fairly common until August 17, 1917. One of the most abundant and characteristic birds of the badlands and sage flats in 1971. Seems to favor sagebrush/woodland or tall shrub edges.

Dark-eyed Junco - Migrants arrived on September 17, 1917.

Chipping Sparrow - Quite common until the first week of September, 1917

${ }^{*}$ Clay-colored Sparrow - Reported as common by Taverner. Fairly common in 1971 in areas of low shrubs

*Brewer's Sparrow - Noted with certainty only on July 6, 1971, in a sage brush flat. Subsequent observations by Wallis and Wershler indicate that this species is scarce along this section of the river. It is more common downstream on more extensive sagebrush flats (Wallis).

White-crowned Sparrow - A common species after September 3, 1917. Also seen by Wershler on May 12, 1977. 
White-throated Sparrow - Young found small numbers after August 22, 1917. ${ }^{17}$

Lincoln's Sparrow - Young did not see them until after August 25; they grew more common and were "very numerous" on September 5, 1917. ${ }^{17}$

* Song Sparrow - Reported as common by Taverner. Only recorded once in my field notes and apparently uncommon in 1971. In sandbar willows, occasional on May 27 and 28, 1975.

* Lapland Longspur - Taverner reported them from September 10 to 15, 1917.

${ }^{*}$ Chestnut-collared Longspur - One on July 26, 1917; fairly common September 1013 and no more until two on September 20. Birds were occasionally seen in 1971 on the prairie.

DISCUSSION. The known park avifauna consists of 130 species, 64 of which nest regularly. The remainder are migrants (43 species) and visitors from surrounding areas (17 species). Additions will consist largely of prairie species that breed in surrounding areas and migrants. The riparian tree and shrub habitats are attractive to migrating passerines and some migrating shorebirds are certain to use the river shores.

The breeding birds of Alberta consist roughly of one-half passerine species and one-half non-passerines (with a slight preponderance of passerines). The breeding avifauna of the prairie region of Alberta (exclusive of the Cypress Hills and elements introduced by the coniferous forests of the middle Red Deer River) is also roughly 50:50, with non-passerines having a slight preponderance in this instance. In the case of Dinosaur Park, the ratio of regularly breeding passerine to non-passerine species is almost 2 to 1 . Thus, even at a very general level the birds of the park are not representative of either provincial or prairie avifauna.

Playing a minor role in the breeding park avifauna are aquatic birds such as grebes, most ducks, gulls and shorebirds. This can be attributed to a general lack of suitable habita resulting from the prime reason for th establishment of the park. The par boundary was established primarily $t$ include the fossil-rich badlands whic contain virtually no natural aquati habitats. The small areas of prair within the park only contain smal ephemeral wetlands incapable supporting a regularly breedin aquatic avifauna.

The regularly breeding park birc are dominated by aerial insectivorol and seed-eating passerines. Thes however are not representative prairie grasslands. Rather, the represent the distinct avifauna riparian and badlands habita characteristic of certain of the larg streams in southern Alberta. Despit small differences related to i complete knowledge and th geographic range of certain specie the park avifauna is similar to th reported from similar habitats alor the middle Red Deer River, the Mi River canyon area and even a portic of the Missouri River breaks

Montana. ${ }^{11} 102120$

The park supports species from 8 the 12 passerine "Bird Faunas" prese in Canada as described by Udvardy These are Black-capped Chickadee the Boreal Forest Fauna; Lea Flycatcher, Veery and Vesper Sparrc of the Eastern Ecotone Fauna; Nc thern Oriole, Brown Thrasher, Catbi and Red-eyed Vireo of the Easte Deciduous Forest Fauna; Sprague Pipit and Chestnut-collared Longsp of the Prairie Fauna; Western Wor Peewee of the Western Conifero Forest Fauna; Western Meadowla and Brewer's Blackbird of the Weste Woodand Edge Fauna; Say's Phoel Black-billed Magpie and Mounta Bluebird of the Creat Basin Fauna; a Rock Wren of the Trans-Tehuantep Montane Fauna. The breeding pa avifauna is dominated by species wi 
eastern and southern affinities. Situated just east of an area identified as having an extremely high Index of Faunal Change, relatively few representatives of northern and western faunas manage to reach the park area. ${ }^{3}$

Human activity, both locally and on a continental level, has contributed to changes in the park avifauna. The Ring-necked Pheasant, Rock Dove, Starling and House Sparrow have only begun using the park since Taverner's visit in 1917. The Turkey Vulture and Peregrine Falcon no longer occur regularly. This can be attributed to the demise of the bison and the advent of pesticides, respectively. The Western Kingbird, Black-headed Grosbeak, and bullocki subspecies of the Northern Oriole have not been recently reported. Rising suggests that the bullocki species range has been depressed to the south during the past century, possibly due to climatic changes. ${ }^{15}$ Climatic changes may also help account for the absence of the Black-headed Grosbeak. The absence of the Western Kingbird is puzzling and may even be a temporary phenomenon resulting from regional population fluctuations. The numbers of Mourning Dove have increased and the Ferruginous Hawk has apparently decreased since 1917. Reasons for these changes are not clear, although increased grain crops and reduced ground squirrel populations may be partial explanations.

The decimating effects of the House Sparrow and Starling on Mountain Bluebird populations is known from numerous localities. In contrast, the Mountain Bluebird has survived well in the badlands of Dinosaur Park and other badlands areas of southern Alberta. The Red-winged Blackbird is now present as a breeding species due to habitat changes triggered by irrigation. This has led to the valleys of One Tree Creek, Sandhill Creek and

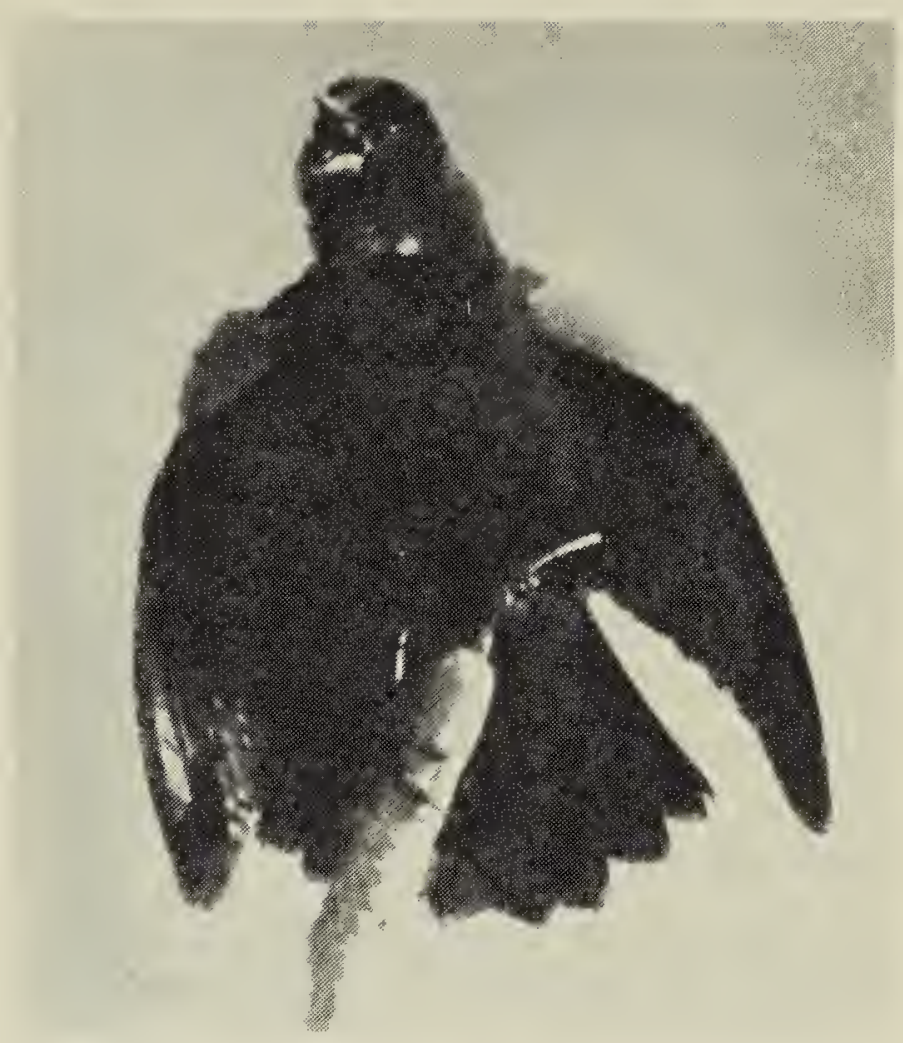

Redwinged Blackbird

Fred W. Lahrman

two unnamed streams receiving an unnaturally abundant infusion of water during the past 50 years. Aquatic vegetation has developed and riparian shrubbery has expanded to the point where breeding bird populations have been substantially altered.

Of the three physiographic regions, the river terrace region supports the greatest variety of bird species and the highest populations per unit area. This is probably due to the variety of nesting substrates as well as the relatively high plant productivity which increases seed and insect food sources. Colonies of Bank Swallows capitalize on the sandy cutbanks for nest sites while Northern Yellowthroats occupy the sandbar willow thickets on the younger portions of the terraces. Cottonwood stands are frequented by species such as the Least Flycatcher, House Wren, Common Flicker, Eastern Kingbird and Merlin. The tall shrub ecotone between cottonwood stands and sagebrush flats is home to species such as the Brown Thrasher, Rufoussided Towhee, Yellow Warbler, and Lark Sparrow. Sagebrush flats are used as foraging sites by a number of species but the most regular nesting 
species dependent on this habitat are the Brewer's Sparrow and Grasshopper Sparrow.

Vegetation and landform variation in the badlands is on a micro-scale, thereby failing to provide minimum areas needed for certain species. For example, Horned Larks were not found nesting in the badlands although grassland habitat is abundant - in small, scattered areas. The most abundant and characteristic species of the badlands are the Mountain Bluebird, Rock Wren, Say's Phoebe and Lark Sparrow.

The prairie region, with the least variation in land form and vegetation structure, supports the fewest numbers of birds and species. Typical species are the Horned Lark and Chestnutcollared Longspur.

'CAMPBELL, I. A. 1970. Erosion rates in the Steveville badlands, Alberta. Canadian Geographer 9:202-216

${ }^{2}$ HANSON, H. C. 1965. The Giant Canada Goose. Southern Illinois Univ. Press. 226 pp.

${ }^{3}$ KAISER, G. W., L. P. LEFKOVITCH, and H. F. HOWDEN. 1972. Faunal provinces in Canada as exemplified by mammals and birds: a mathematical consideration. Canadian Zool. 50:1087-1104

${ }^{4}$ KJEARSGAARD, A. A. 1972. Soils of the Dinosaur Provincial Park. Alberta Inst. of Pedology, Report No. M-72-4, 3 pp.

${ }^{5}$ KONDLA, N. G. 1972. Use of Barn Swallow nests by phoebes. Calgary Field Nat. 3:158-159

${ }^{6}$ KONDLA, N. C. 1973. Canada Goose goslings leaving cliff nest. Auk 90:890

${ }^{7}$ KONDLA, N. G. and H. R. CRAWFORD. 1971. An ecological survey of Dinosaur Provincial Park. Parks Planning Branch, Alberta Department of Lands and Forests. Unpub. Rep. 82 pp. +17 maps.

${ }^{8}$ KONDLA, N. G. and H. W. PINEL. 1971. Some noteworthy records of cowbird parasitism in Southern Alberta. Blue Jay 29:204-207.
${ }^{9}$ KONDLA, N. G. and H. W. PINEL. 197 Breeding records of 19 species of birds southern Alberta. Blue Jay 31:153-157.

${ }^{10} \mathrm{KONDLA}, \mathrm{N}$. G., H. W. PINEL, C. WALLIS, and C. R. WERSHLER. 197 Avifauna of the Drumbeller are Alberta. Canadian Field Nat. 87:377-393

${ }^{11}$ KONDLA, N. G. and W. W. SMITH. 197 An ecological survey of Dry Islan Buffalo Jump Provincial Park. Park Planning Branch, Alberta Department $c$ Lands and Forests. Unpubl. Rep., Volume I, $55 \mathrm{pp}$.

${ }^{12}$ LONGLEY, R. W. 1972. The climate of th Prairie Provinces. Environment Canad Atmospheric Environment, Clima tological Studies. No. 13, 79pp.

${ }^{13}$ MCPHERSON, H. J. 1969. Flow, channe and floodplain characteristics of th lower Red Deer River, Alberta. pp. 25: 279 in Nelson, J. G. and M. J. Chambe (ed.). Geomorphology. Methuen, $399 \mathrm{pp}$

${ }^{14}$ RANDALL, T. E. 1946. Birds of the Easter Irrigation District, Brooks, Albert Canadian Field-Nat. 60:123-131.

${ }^{15}$ RISING, J. D. 1973. Morphologica variation and status of the orioles, $I$ terus galbula, I. bullockii, and I. abeille in the northern Great Plains and i Durango, Mexico. Canadian J. of Zoo 51:1267-1273.

${ }^{16}$ SALT, W. R. 1973. Alberta vireos and woo warblers. Prov. Mus. and Archives Alberta, Publ. No. 3.141 pp.

17TAVERNER, P. A. 1919. The birds of th Red Deer River, Alberta. Auk 36:1-2 248-265.

${ }^{18}$ UDVARDY, M. D. F. 1963. Bird faunas c North America. Proceedings Interna Ornith. Congr. 13:1147-1167.

${ }^{19}$ VERMEER, K. 1969. Great Blue Hero colonies in Alberta. Canadian Field- $\mathrm{Na}$ 83:237-242.

${ }^{20}$ WALCHECK, K. C. 1970. Nesting bir ecology of four plant communities in th Missouri River breaks, Montana. Wilso Bull. 82:370-382.

${ }^{21}$ WALLIS, C. A. 1976. Milk River Canyo resource evaluation. Parks Planning an Design Branch, Alberta Recreatior Parks and Wildlife. Unpubl. Rep. 122 pp 